Marquette University

e-Publications@Marquette

Theology Faculty Research and Publications

Theology, Department of

$1-1-2004$

Celestial Choirmaster: The Liturgical Role of Enoch-Metatron in 2 Enoch and Merkabah Tradition

Andrei Orlov

Marquette University, andrei.orlov@marquette.edu

Author version. Journal for the Study of the Pseudepigrapha, Volume 14, No. 1 (2004): 3-29. DOI: (C) 2004 SAGE Publications. Used with permission. 


\title{
Celestial Choirmaster: The Liturgical Role of Enoch-Metatron in 2 Enoch and the Merkabah Tradition
}

\author{
Andrei A. Orlov \\ Theology Department, Marquette University \\ Milwaukee, WI
}

\section{Introduction}

In one of his recent publications, Philip Alexander traces the development of Enoch's image through the Jewish literature of the Second Temple period up to the early Middle Ages. ${ }^{1}$ His study points to "a genuine, ongoing tradition" that shows the astonishing persistence of certain motifs. As an example, Alexander explicates the evolution of Enoch's priestly role which was prominent in the Second Temple materials and underwent in the later Merkabah sources further development in Metatron's sacerdotal duties. He observes that "Enoch in Jubilees in the second century BCE is a high priest. Almost a thousand years later he retains this role in the Heikhalot texts, though in a rather different setting." 2 Noting the long-lasting association of Enoch-Metatron ${ }^{3}$ with the sacerdotal office, Alexander draws attention to the priestly role of this exalted figure attested in 3 Enoch 15B where Enoch- Metatron is put in charge of the heavenly tabernacle. The passage from Sefer Hekhalot reads:

Metatron is the Prince over all princes, and stands before him who is exalted above all gods. He goes beneath the Throne of Glory, where he has a great

Journal for the Study of the Pseudepigrapha, Vol. 14, No. 1 (2004): pg. 3-29. DOI. This article is (C) SAGE Publisher and permission has been granted for this version to appear in e-Publications@Marquette. SAGE Publisher does not grant permission for this article to be further copied/distributed or hosted elsewhere without the express permission from SAGE Publisher. 
heavenly tabernacle of light, and brings out the deafening fire, and puts it in the ears of the holy creatures, so that they should not hear the sound of the utterance that issues from the mouth of the Almighty. ${ }^{4}$

This passage portrays the translated patriarch as a heavenly priest in the celestial tabernacle located beneath God's Kavod. Along with the reference to Metatron's role as the sacerdotal servant, the text also alludes to another, more enigmatic tradition in which this angel is depicted as the one who inserts "the deafening fire" into the ears of the hayyot so the holy creatures will not be harmed by the voice of the Almighty. This reference might allude to another distinctive role of the exalted angel, to his office of the celestial choirmaster, that is, one who directs the angelic liturgy taking place before the Throne of Glory. The tradition attested in 3 Enoch 15B, however, does not explicate this role of Metatron, most likely because of the fragmentary nature of this passage which is considered by scholars as a late addition to Sefer Hekhalot. ${ }^{5}$ A similar description in Synopse $390^{6}$ appears to have preserved better the original tradition about Metatron's unique liturgical role. The text relates:

One hayyah rises above the seraphim and descends upon the tabernacle of the youth ( $\mathrm{r}(\mathrm{nh} \mathrm{Nk \# m})$ whose name is Metatron, and says in a great voice, a voice of sheer silence: "The Throne of Glory is shining." Suddenly the angels fall silent. The watchers and the holy ones become quiet. They are silent, and are pushed into the river of fire. The hayyot put their faces on the ground, and this youth whose name is Metatron brings the fire of deafness and puts it into their ears so that they could not hear the sound of God's speech or the ineffable name. The youth whose name is Metatron then invokes, in seven voices (twlwq h (b\#b h (\# tw) b rykzm Nwr++m wm\#\# r(nh\#), his living, pure, honored, awesome, holy, noble, strong, beloved, mighty, powerful name. ${ }^{7}$

Here again the themes of Metatron's priesthood in the heavenly tabernacle and his duty of bringing the fire of deafness to the hayyot are conflated. This passage also indicates that Metatron is not only the one who protects and prepares the heavenly hosts for their praise to the deity, ${ }^{8}$ but also the choirmaster who himself conducts the liturgical ceremony by invoking the divine name. The passage underlines the extraordinary scope of Metatron's own vocal abilities that allow him to 
invoke the deity's name in seven voices. Yet the portrayal of this celestial choirmaster intentionally "deafening" the members of his own choir might appear puzzling. A close examination of Hekhalot liturgical theology may however help clarify the paradoxal imagery. Peter Schäfer points out that in the Hekhalot writings "the heavenly praise is directed solely toward God" since "for all others who hear it-men as well as angels-it can be destructive. ${ }^{\prime 9}$ As an example, Schäfer refers to a passage from Hekhalot Rabbati which offers a chain of warnings about the grave dangers encountered by those who dare to hear the angelic praise. ${ }^{10}$ James Davila's recent study also confirms the importance of the motif of the dangerous encounters in the course of the heavenly worship in Hekhalot liturgical settings. ${ }^{11}$

This motif may constitute one of the main reasons for Metatron's preventive ritual of putting the deafening fire into the ears of the holy creatures. ${ }^{12}$ It is also helpful to realize that YouthMetatron's role of safeguarding the angelic hosts stems directly from his duties as the liturgical servant and the director of angelic hosts.

It should be stressed that while Enoch-Metatron's liturgical office plays a prominent role in the Merkabah lore, this tradition appears to be absent in early Enochic texts, including the compositions collected in 1 Enoch, Jubilees, Genesis Apocryphon and the Book of Giants. Despite this apparent absence, this study will argue that the roots of Enoch-Metatron's liturgical imagery can be traced to the Second Temple Enochic lore, namely, to 2 Enoch, the Jewish apocalypse, apparently written in the first century CE. Some traditions found in this text appear to serve as the initial background for the developments of the future liturgical role of Enoch-Metatron as the celestial choirmaster. This study will focus on investigating these developments.

\section{Priestly Role of the Seventh Antediluvian Patriarch in Early Enochic Traditions}

Before this study proceeds to a detailed analysis of the liturgical role of the translated patriarch in 2 Enoch and the Merkabah tradition, a brief introduction to the priestly and liturgical function of the seventh antediluvian hero in the pseudepigraphical materials is needed. 
In early Enochic booklets the seventh antediluvian patriarch is closely associated with the celestial sanctuary located, as in the later Merkabah lore, in the immediate proximity to the Divine Throne. Enoch's affiliations with the heavenly Temple in the Book of the Watchers (1 En. 1-36), the Book of Dreams (1 En. 83-90), and the book of Jubilees can be seen as the gradual evolution from the implicit references to his heavenly priesthood in the earliest Enochic materials to a more overt recognition and description of his sacerdotal function in the later ones. While later Enochic traditions attested in the book of Jubilees unambiguously point to Enoch's priestly role by referring to his incense sacrifice in the celestial sanctuary, the earlier associations of the patriarch with the heavenly Temple hinted at in the Book of the Watchers took the form of rather enigmatic depictions. A certain amount of exegetical work is, therefore, required to discern the proper meaning of these initial associations of the patriarch with the celestial sanctuary.

Martha Himmelfarb's research helps to clarify Enoch's possible connections with the celestial sanctuary in the Book of the Watchers, the account of which appears to fashion the ascension of the seventh antediluvian patriarch to the Throne of Glory as a visitation of the heavenly Temple.13 1 Enoch $14.9-18$ reads:

And I proceeded until I came near to a wall which was built of hailstones, and a tongue of fire surrounded it, and it began to make me afraid. And I went into the tongue of fire and came near to a large house which was built of hailstones, and the wall of that house (was) like a mosaic (made) of hailstones, and its floor (was) snow. Its roof (was) like the path of the stars and flashes of lightning, and among them (were) fiery Cherubim, and their heaven (was like) water. And (there was) a fire burning around its wall, and its door was ablaze with fire. And I went into that house, and (it was) hot as fire and cold as snow, and there was neither pleasure nor life in it. Fear covered me and trembling, I fell on my face. And I saw in the vision, and behold, another house, which was larger that the former, and all its doors (were) open before me, and (it was) built of a tongue of fire. And in everything it so excelled in glory and splendor and size that I am unable to describe for you its glory and its size. And its floor (was) fire, and above (were) lightning and the path of the stars, and its roof also (was) a burning fire. And I looked and I saw in it a high throne, and its appearance (was) like ice and its surrounds like the shining sun and the sound of Cherubim. ${ }^{14}$

Commenting on this passage, Himmelfarb draws attention to the description of the celestial edifices which Enoch encounters in his 
approach to the Throne. She notes that the Ethiopic text reports that, in order to reach God's Throne, the patriarch passes through three celestial constructions: a wall, an outer house, and an inner house. The Greek version of this narrative mentions a house instead of a wall. Himmelfarb observes that "more clearly in the Greek, but also in the Ethiopic this arrangement echoes the structure of the earthly temple with its vestibule $(\mathrm{Ml} \mathrm{w})$ ), sanctuary ( $1 \mathrm{kyh})$, and holy of holies (rybd)."15 God's Throne is located in the innermost chamber of this heavenly structure and is represented by a throne of cherubim. It can be seen as a heavenly counterpart to the cherubim found in the Holy of Holies in the Jerusalem Temple. ${ }^{16}$ In drawing parallels between the descriptions of the heavenly Temple in the Book of the Watchers and the features of the earthly sanctuary, Himmelfarb observes that the "fiery cherubim" which Enoch sees on the ceiling of the first house (Ethiopic) or middle house (Greek) of the heavenly structure represent, not the cherubim of the divine Throne, but images that recall the figures on the hangings on the wall of the terrestrial tabernacle mentioned in Exod. 26:1, 31; 36:8, 35 or possibly the figures which, according $1 \mathrm{Kgs} 6: 29,2$ Chron. 3:7 and Ezek. 41:15-26, were engraved on the walls of the earthly Temple. ${ }^{17}$

Several words must be said about the servants of the heavenly sanctuary depicted in 1 Enoch 14 . Himmelfarb observes that the priests of the heavenly Temple in the Book of the Watchers appear to be represented by angels, since the author of the text depicts them as the ones "standing before God's Throne in the heavenly temple."18 She also points to the possibility that in the Book of the Watchers the patriarch himself in the course of his ascent becomes a priest ${ }^{19}$ similarly to the angels. " 20 In this perspective, the angelic status of the patriarch and his priestly role ${ }^{21}$ are viewed as mutually interconnected. Himmelfarb stresses that "the author of the Book of the Watchers claims angelic status for Enoch through his service in the heavenly temple" since "the ascent shows him passing through the outer court of the temple and the sanctuary to the door of the holy of holies, where God addresses him with his own mouth." 22 It is important for our investigation to note that, despite the fact that Enoch appears to be envisioned as an angel by the authors of the text, nothing is said about his leading role in the angelic liturgy.

Journal for the Study of the Pseudepigrapha, Vol. 14, No. 1 (2004): pg. 3-29. DOI. This article is (C) SAGE Publisher and permission has been granted for this version to appear in e-Publications@Marquette. SAGE Publisher does not grant permission for this article to be further copied/distributed or hosted elsewhere without the express permission from SAGE Publisher. 
NOT THE PUBLISHED VERSION; this is the author's final, peer-reviewed manuscript. The published version may be accessed by following the link in the citation at the bottom of the page.

The traditions about the seventh patriarch's heavenly priesthood are not confined solely to the materials found in the Book of the Watchers, since they are attested in other 1 Enoch's materials, including the Animal Apocalypse (1 En. 85-90).

It is noteworthy that, whereas in the Book of the Watchers Enoch's associations with the heavenly Temple are clothed with rather ambiguous imagery, his depictions in the Animal Apocalypse do not leave any serious doubts that some of the early Enochic traditions understood Enoch to be intimately connected with the heavenly sanctuary.

Chapter 87 of 1 Enoch portrays the patriarch taken by three angels from the earth and raised to a high tower, where he is expected to remain until he will see the judgment prepared for the Watchers and their earthly families. 1 Enoch $87: 3-4$ reads:

And those three who came out last took hold of me by my hand, and raised me from the generations of the earth, and lifted me on to a high place, and showed me a tower high above the earth, and all the hills were lower. And one said to me: "Remain here until you have seen everything which is coming upon these elephants and camels and asses, and upon the stars, and upon all the bulls." 23

James VanderKam notes a significant detail in this description, namely, Enoch's association with a tower. He observes that this term ${ }^{24}$ is reserved in the Animal Apocalypse for a Temple. ${ }^{25}$ The association of the patriarch with the tower is long-lasting, and apparently he must have spent there a considerable amount of time, since the text does not say anything about Enoch's return to the earth again until the time of judgment. So the patriarch is depicted as present in the heavenly sanctuary for most of the Animal Apocalypse. ${ }^{26}$

Although the traditions about Enoch's associations with the heavenly Temple in the Book of the Watchers and in the Animal Apocalypse do not refer explicitly to his performance of the priestly duties, the account attested in the book of Jubilees explicitly makes this reference.

Journal for the Study of the Pseudepigrapha, Vol. 14, No. 1 (2004): pg. 3-29. DOI. This article is (C) SAGE Publisher and permission has been granted for this version to appear in e-Publications@Marquette. SAGE Publisher does not grant permission for this article to be further copied/distributed or hosted elsewhere without the express permission from SAGE Publisher. 
NOT THE PUBLISHED VERSION; this is the author's final, peer-reviewed manuscript. The published version may be accessed by following the link in the citation at the bottom of the page.

Jubilees 4:23 depicts Enoch to be taken from human society and placed in Eden ${ }^{27}$ "for (his) greatness and honor." 28 The Garden is then defined as a sanctuary ${ }^{29}$ and Enoch as one who is offering an incense sacrifice on the mountain of incense: "He burned the evening incense ${ }^{30}$ of the sanctuary which is acceptable before the Lord on the mountain of incense." 31

VanderKam suggests that here Enoch is depicted as one who "performs the rites of a priest in the temple." 32 Furthermore, he observes that Enoch's priestly duties represent a new element in "Enoch's expanding portfolio." 33

The purpose of the aforementioned analysis was to demonstrate that, despite the fact that the early Enochic materials found in 1 Enoch and Jubilees emphasize the patriarch's association with the heavenly sanctuary, they do not contain any references to his role in directing the celestial liturgy. Unlike the later Merkabah materials where the priestly duties of Enoch-Metatron are often juxtaposed with his liturgical activities, early Enochic lore does not link these two sacerdotal functions. Moreover, it appears that in 1 Enoch and Jubilees Enoch does not play any leading role in the celestial liturgy. Thus, for example, in the Book of the Similitudes (1 En. 37-71), where the celestial liturgy plays an important part, the patriarch does not play any significant role (1 En. 39). Moreover, the text stresses that Enoch is unable to sustain the frightening "Presence" of the deity. In 1 Enoch 39:14 the patriarch laments that during celestial liturgy his "face was transformed" until he was not able to see. ${ }^{34}$ This lament makes clear that Enoch's capacities can in no way be compared with MetatronYouth's potentialities which are able not only to sustain the terrifying Presence of the deity but also to protect others, including the angelic hosts during the celestial liturgy.

These conceptual developments indicate that in the early Enochic materials the leading role of the translated patriarch in the sacerdotal settings remains solely priestly, but not liturgical. Unlike the later Merkabah materials where the theme of the celestial sanctuary (the tabernacle of the Youth) is often conflated with Metatron's role as the celestial choirmaster, the early Enochic materials associated with 1 Enoch and Jubilees show only one side of the story. Our study must 
now proceed to the testimonies about Metatron's priestly and liturgical activities in the Hekhalot and the Shicur Qomah materials.

\section{Tabernacle of the Youth: Priestly and Liturgical Roles of Enoch-Metatron in the Merkabah Tradition}

It has been already mentioned that, in contrast to the early Enochic booklets which do not provide any hints as to Enoch's leading role in the heavenly liturgy, in the Merkabah tradition the priestly role of Enoch-Metatron is closely intertwined with his pivotal place in the course of the angelic worship. Since both of these sacerdotal functions are closely interconnected, before we proceed to a detailed analysis of the liturgical imagery associated with this exalted angel, we must explore Metatron's priestly duties, which in many respects echo and develop further the earlier Enochic traditions about the sacerdotal duties of the seventh antediluvian hero.

\section{Heavenly High Priest}

While the early Enochic materials depict the seventh antediluvian patriarch as a newcomer who just arrives to his new appointment in the heavenly sanctuary, the Merkabah materials portray Metatron as an established celestial citizen who is firmly placed in his sacerdotal office and even possesses his own heavenly sanctuary that now bears his name. Thus in the passage found in Merkabah Shelemah the heavenly tabernacle is called the "tabernacle of Metatron" (Nwr++m Nk\#m). In the tradition preserved in Num. R. 12.12, the heavenly sanctuary again is associated with one of Metatron's designations and is named the "tabernacle of the Youth" ( $r$ ( $\mathrm{nh}$ $\mathrm{Nk} \# \mathrm{~m}): 35$

R. Simon expounded: When the Holy One, blessed be He, told Israel to set up the Tabernacle He intimated to the ministering angels that they also should make a Tabernacle, and the one below was erected the other was erected on high. The latter was the tabernacle of the youth $(\mathrm{r}(\mathrm{nh} \mathrm{Nk \# m)}$ whose name was Metatron, and therein he offers up the souls of the righteous to atone for Israel in the days of their exile. ${ }^{36}$ 
This close association between the exalted angel and the upper sanctuary becomes quite widespread in the Hekhalot lore where the celestial Temple is often called the tabernacle of the Youth. ${ }^{37}$

A significant detail of the rabbinic and Hekhalot descriptions of the tabernacle of the Youth is that this structure is placed in the immediate proximity to the Throne, more precisely right beneath the seat of Glory. ${ }^{38}$ As mentioned in the introduction, 3 Enoch 15B locates Enoch-Metatron's "great heavenly tabernacle of light" beneath the Throne of Glory. ${ }^{39}$ This tradition appears to be not confined solely to the description attested in 3 Enoch since several Hekhalot passages depict Youth (who often is identified there with Metatron $)^{40}$ as the one who emerges from beneath the Throne. ${ }^{41}$ The proximity of the tabernacle to Kavod recalls the early Enochic materials, more specifically 1 Enoch 14, where the patriarch's visitation of the celestial sanctuary is described as his approach to God's Throne. Both Enochic and Hekhalot traditions seem to allude here to Enoch-Metatron's role as the celestial high priest since he approaches the realm where the ordinary angelic or human creatures are not allowed to enter, namely, the realm of the immediate Presence of the deity, the place of the Holy of Holies, which is situated behind the veil, represented by heavenly $(d w g r p)^{42}$ or terrestrial (tkrp) curtains. Metatron's service behind the heavenly curtain parallels the unique function of the earthly high priest who alone was allowed to enter behind the veil of the terrestrial sanctuary. ${ }^{43}$ It has been mentioned that the possible background of this unique role of Metatron can be traced to the Enochic materials, more specifically to 1 Enoch 14 where the patriarch alone appears in the celestial Holy of Holies while the other angels are barred from the inner house. This depiction also correlates with the Hekhalot evidence according to which only the Youth, that is, Metatron, similarly to the earthly high priest, is allowed to serve before as well as behind the heavenly veil. The inscription on one Mandean bowl describes Metatron as the attendant "who serves before the Curtain." 44 Philip Alexander observes that this definition "may be linked to the Hekhalot tradition about Metatron as the heavenly High Priest ... and certainly alludes to his status as 'Prince of the Divine Presence. '"'45 It is true that Metatron's role as the Prince of the Divine Presence or the Prince of the Face (Sar ha-Panim) cannot be separated from his priestly and liturgical duties since both the tabernacle of this exalted angel and the 
divine liturgy that he is conducting are situated in the immediate proximity to God's Presence, also known as his Face. In relation to our investigation of the liturgical imagery, it is worth noting that by virtue of being God's Sar ha-Panim Youth-Metatron can unconditionally approach the Presence of the deity without harm for himself, a unique privilege denied to the rest of the created order. He is also allowed to go behind the Curtain and behold the Face of God, ${ }^{46}$ as well as to hear the voice of the deity. This is why he is able to protect the hayyot against the harmful effects of the Divine Presence in the course of the angelic liturgy. Such imagery points to the fact that Metatron's bold approach to the Divine Presence is predetermined, not only by his special role as the celestial High Priest, but also by his privileges in the office of the Prince of the Divine Presence.

It should be noted that, in contrast to the early Enochic traditions which hesitate to name explicitly the exalted patriarch as the high priest, the Merkabah materials directly apply this designation to Metatron. Rachel Elior observes that Metatron appears in the Genizah documents as a high priest who offers sacrifices on the heavenly altar. ${ }^{47}$ She draws attention to the important testimony attested in one Cairo Genizah text which labels Metatron as the high priest and the chief of the priests. The text reads:

I adjure you [Metatron], more beloved and dear than all heavenly beings, [Faithful servant] of the God of Israel, the High Priest (lwdg Nhk), chief of [the priest]s (M[ynhkh] \#) r), you who poss[ess seven]ty names; and whose name[is like your Master's] ... Great Prince, who is appointed over the great princes, who is the head of all the camps. ${ }^{48}$

It is also noteworthy that Metatron's role as the heavenly high priest appears to be supported in the Hekhalot materials by the motif of the peculiar sacerdotal duties of the terrestrial protagonist of the Hekhalot literature, Rabbi Ishmael b. Elisha, to whom Metatron serves as an angelus interpres. In view of Enoch-Metatron sacerdotal affiliations, it is not coincidental that Rabbi Ishmael is the tanna who is attested in $b$. Ber. 7a as a high priest. ${ }^{49}$ R. Elior observes that in Hekhalot Rabbati this rabbinic authority is portrayed in terms similar to those used in the Talmud, that is, as a priest burning an offering on the altar. ${ }^{50}$ Other Hekhalot materials, including 3 Enoch, ${ }^{51}$ also often refer to R. Ishmael's priestly origins. The priestly features of this visionary might

Journal for the Study of the Pseudepigrapha, Vol. 14, No. 1 (2004): pg. 3-29. DOI. This article is (C) SAGE Publisher and permission has been granted for this version to appear in e-Publications@Marquette. SAGE Publisher does not grant permission for this article to be further copied/distributed or hosted elsewhere without the express permission from SAGE Publisher. 
NOT THE PUBLISHED VERSION; this is the author's final, peer-reviewed manuscript. The published version may be accessed by following the link in the citation at the bottom of the page.

not only reflect the heavenly priesthood of Metatron52 but also allude to the former priestly duties of the patriarch Enoch known from 1 Enoch and Jubilees, since some scholars note that " 3 Enoch presents a significant parallelism between the ascension of Ishmael and the ascension of Enoch." 53

\section{Celestial Choirmaster}

Unlike the early Enochic booklets that unveil only the patriarch's leading role in the priestly settings, the Merkabah materials emphasize another important dimension of his activities in the divine worship, namely, the liturgical aspect of his celestial duties. The passages from 3 Enoch 15B and Synopse $\S 390$ that began our investigation show that one of the features of Metatron's service in the heavenly realm involves his leadership over the angelic hosts delivering heavenly praise to the deity. Metatron is portrayed there not just as a servant in the celestial tabernacle or the heavenly high priest, but also as the leader of the heavenly liturgy. The evidences that unfold Metatron's liturgical role are not confined solely to the Hekhalot corpus, but can also be detected in another prominent literary stream associated with early Jewish mysticism which is represented by the Shicur Qomah materials. The passages found in the Shicur Qomah texts attest to a familiar tradition in which Metatron is posited as a liturgical servant. Thus, Sefer Haqqomah 155-164 reads:

And (the) angels who are with him come and encircle the Throne of Glory. They are on one side and the (celestial) creatures are on the other side, and the Shekhinah is on the Throne of Glory in the center. And one creature goes up over the seraphim and descends on the tabernacle of the lad whose name is Metatron and says in a great voice, a thin voice of silence, "The Throne of Glory is glistening!" Immediately, the angels fall silent and the cirin and the qadushin are still. They hurry and hasten into the river of fire. And the celestial creatures turn their faces towards the earth, and this lad whose name is Metatron, brings the fire of deafness and puts (it) in the ears of the celestial creatures so that they do not hear the sound of the speech of the Holy One, blessed be $\mathrm{He}$, and the explicit name that the lad, whose name is Metatron, utters at that time in seven voices, in seventy voices, in living, pure, honored, holy, awesome, worthy, brave, strong, and holy name. ${ }^{54}$

A similar tradition can be found in Siddur Rabbah 37-46, another text associated with Shicur Qomah tradition, where the angelic Youth however is not identified with the angel Metatron:

Journal for the Study of the Pseudepigrapha, Vol. 14, No. 1 (2004): pg. 3-29. DOI. This article is (C) SAGE Publisher and permission has been granted for this version to appear in e-Publications@Marquette. SAGE Publisher does not grant permission for this article to be further copied/distributed or hosted elsewhere without the express permission from SAGE Publisher. 
The angels who are with him come and encircle the (Throne of) Glory; they are on one side and the celestial creatures are on the other side, and the Shekhinah is in the center. And one creature ascends above the Throne of Glory and touches the seraphim and descends on the Tabernacle of the Lad and declares in a great voice, (which is also) a voice of silence, "The throne alone shall I exalt over him." The ofanim become silent (and) the seraphim are still. The platoons of cirin and qadushin are shoved into the River of Fire and the celestial creatures turn their faces downward, and the lad brings the fire silently and puts it in their ears so that they do not hear the spoken voice; he remains (thereupon) alone. And the lad calls Him, "the great, mighty and awesome, noble, strong, powerful, pure and holy, and the strong and precious and worthy, shining and innocent, beloved and wondrous and exalted and supernal and resplendent God. ${ }^{55}$

In reference to these materials M. Cohen notes that in the Shicur Qomah tradition Metatron's service in the heavenly tabernacle appears to be "entirely liturgical" and "is more the heavenly choirmaster and beadle than the celestial high priest."

It is evident that the tradition preserved in Sefer Haqqomah cannot be separated from the microforms found in Synopse 390 and 3 Enoch 15B since all these narratives are unified by a similar structure and terminology. All of them also emphasize the Youth's leading role in the course of the celestial service. It is also significant that Metatron's role as the one who is responsible for the protection and encouragement of the servants delivering praise to the deity is not confined only to the aforementioned passages, but finds support in the broader context of the Hekhalot and Shicur Qomah materials. ${ }^{57}$

Thus, in the Hekhalot corpus, Metatron's duties as the choirmaster or the celestial liturgical director appear to be applied, not only to his leadership over angelic hosts, but also over humans, specifically the visionaries who are lucky enough to overcome the angelic opposition and be admitted into the heavenly realm. In $3 \mathrm{En}$. 1.9-10 Enoch-Metatron is depicted as the one who "prepares" one of such visionaries, Rabbi Ishmael, for singing praise to the Holy One:

At once Metatron, Prince of the Divine Presence, came and revived me and raised me to my feet, but still I had no strength enough to sing a hymn before the glorious throne of the glorious King... ${ }^{58}$ 
It is possible that these descriptions of Enoch-Metatron as the one who encourages angels and humans to perform heavenly praise in front of God's Presence might have their roots in early Second Temple materials. Our investigation must now turn to analyzing some of these early developments that might constitute the early background of the Merkabah liturgical imagery.

\section{The Beginnings: Liturgical Role of Enoch in Slavonic Apocalypse}

One of the texts which might contain early traces of EnochMetatron's liturgical imagery is 2 (Slavonic) Enoch, the Jewish apocalypse, apparently written in the first century CE. In contrast to other early Enochic materials, such as 1 Enoch and Jubilees, which emphasize only one side of the patriarch's heavenly service through the reference to Enoch's priestly activities, the Slavonic text appears to encompass both sacerdotal dimensions-priestly as well as liturgical. Allusions to the priestly office of the seventh antediluvian hero in the Slavonic text demonstrate marked difference in comparison with the testimonies found in 1 Enoch and Jubilees. Thus, unlike the aforementioned Enochic tracts, 2 Enoch does not associate the translated patriarch with any celestial structure that might remotely resemble the descriptions found in 1 Enoch 14 and 87 . On the other hand, the Slavonic text contains a number of other indirect testimonies that demonstrate that the authors of this apocalypse were cognizant of the patriarch's priestly role. Thus, scholars previously observed that Enoch's anointing with shining oil and his clothing into the luminous garments during his angelic metamorphosis in 2 Enoch 22 appear to resemble the priestly vesture. ${ }^{59}$ Another possible sacerdotal association comes from 2 Enoch 67-69 where the descendants of the seventh antediluvian patriarch, including his son Methuselah, are depicted as the builders of the altar which is erected on the place where Enoch was taken up to heaven. The choice of the location for the terrestrial sanctuary might allude to the peculiar role of the patriarch in relation to the heavenly counterpart of this earthly structure. The Slavonic text also appears to refer to the sacerdotal office of Enoch by portraying the patriarch as the one who in 2 Enoch 59 delivers the sacrificial instructions to his children. All these testimonies show that 2 Enoch's authors were familiar with the

Journal for the Study of the Pseudepigrapha, Vol. 14, No. 1 (2004): pg. 3-29. DOI. This article is (C) SAGE Publisher and permission has been granted for this version to appear in e-Publications@Marquette. SAGE Publisher does not grant permission for this article to be further copied/distributed or hosted elsewhere without the express permission from SAGE Publisher. 
traditions about the priestly affiliations of the seventh antediluvian hero attested also in the early Enochic booklets. However, in contrast to these early materials that mention only Enoch's priestly role, the authors of the Slavonic apocalypse also appear to have knowledge about another prominent office of the translated patriarch-his liturgical activities and his role as the one who encourages and directs the celestial hosts in their daily praise of the creator.

Entertaining this possibility of the Enochic origins of Metatron's role as the leader of the divine worship, we must direct our attention to the passage found in 2 Enoch 18 where the patriarch is depicted as the one who encourages the celestial Watchers to conduct liturgy before the face of God. The longer recension of 2 En. 18.8-9 relates:

And I [Enoch] said, "Why are you waiting for your brothers? And why don't you perform the liturgy ${ }^{60}$ before the face of the Lord? Start up your liturgy, ${ }^{61}$ and perform the liturgy before the face of the Lord, so that you do not enrage your Lord to the limit." And they responded to my recommendation, and they stood in four regiments in this heaven. And behold, while I was standing with those men, 4 trumpets trumpeted in unison with a great sound, and the Watchers burst into singing in unison. And their voice rose in front of the face of the Lord, piteously and touchingly. ${ }^{62}$

One can notice that the imagery of this account represents a vague sketch that only distantly alludes to the future prominent liturgical role of Enoch-Metatron. Yet here, for the first time in the Enochic tradition, the seventh antediluvian patriarch dares to assemble and direct the angelic creatures for their routine job of delivering praise to the deity. The choice of the angelic group, of course, is not coincidental since in various Enochic materials the patriarch is often described as a special envoy to the Watchers, the fallen angels, as well as their faithful celestial brothers.

It is significant that, despite the fact that in 2 Enoch 18 the patriarch gives his advice to the angels situated in the Fifth Heaven, he repeatedly advises them to start liturgy "before the Face of the Lord," that is, in front of the divine Kavod, the exact location where YouthMetatron will later conduct the heavenly worship of the angelic hosts in the Shicur Qomah and Hekhalot accounts. 
The shorter recension of the Slavonic text ${ }^{63}$ adds several significant details among which Enoch's advice to the Watchers to "perform the liturgy in the name of fire" ${ }^{64}$ can be found. This peculiar terminology involving the symbolism of fire appears to allude to the concepts found in the aforementioned Hekhalot liturgical accounts where the imagery of fire, in the form of the references to the deafening fire and angels "bathing" in the fire, plays an important role. The shorter recension also stresses the importance of Enoch's leading role, specifically underscoring that the angels needed "the earnestness" of his recommendation. ${ }^{65}$

The reference of 2 Enoch 18 to the later Youth-Metatron office as the heavenly choirmaster does not appear to be happenstance, since the Slavonic apocalypse alludes to some additional features that recall the later Merkabah liturgical developments. The present study will concentrate on two of such characteristics that enhance Enoch's connection with his newly acquired liturgical office. Both of them are linked to Enoch-Metatron's designations, namely, his titles as "Youth" and the "Servant of the Divine Presence," which appear here for the first time in the Enochic tradition. These titles seem to have direct connection to the liturgical imagery found in the Hekhalot and Shicur Qomah materials where the offices of the Youth and Sar ha-Panim help unfold Metatron's liturgical activities. Our study must now proceed to the investigation of these two titles in 2 Enoch's materials.

\section{The Servant of God's Face}

It has been already observed that Metatron's sacerdotal and liturgical duties cannot be separated from his office as the Sar ha-Panim, the one who can approach God's Presence without limit and hesitation. It is not surprising that in 2 Enoch, which attests to the origins of EnochMetatron's liturgical imagery, one can also find for the first time in the Enochic tradition an explicit reference to the patriarch's role as the Servant of the Divine Presence. ${ }^{66}$

Hugo Odeberg may well be the first scholar to have discovered the characteristics of "the Prince of the Presence" in the long recension of 2 Enoch. He successfully demonstrated in his synopsis of the parallel passages from 2 and 3 Enoch that the phrase "stand before

Journal for the Study of the Pseudepigrapha, Vol. 14, No. 1 (2004): pg. 3-29. DOI. This article is (C) SAGE Publisher and permission has been granted for this version to appear in e-Publications@Marquette. SAGE Publisher does not grant permission for this article to be further copied/distributed or hosted elsewhere without the express permission from SAGE Publisher. 
my face forever" found in the Slavonic apocalypse does not serve there merely as a typical Hebraism, "to be in the presence," but establishes the angelic status of Enoch as Metatron, the Prince of the Presence, Mynph r\#. ${ }^{67}$ In 2 Enoch therefore the patriarch is depicted not as one of the visonaries who has only temporary access to the Divine Presence, but as an angelic servant permanently installed in the office of the Sar ha-Panim. The title itself is developed primarily in chs. 21-22, which are devoted to the description of the Throne of Glory. In these chapters, one can find several promises coming from the mouth of Archangel Gabriel and the deity himself that the translated patriarch will now stand in front God's face forever. ${ }^{68}$

In terms of the theological background of the problem, the title seems to be connected with the image of Metatron in the Merkabah tradition, ${ }^{69}$ which was crystallized in the classical Hekhalot literature. ${ }^{70}$ According to the legend of the Hekhalot tradition, Enoch "was raised to the rank of first of the angels and Mynph $r \#$ (literally, 'Prince of the Divine Face,' or 'Divine Presence')."71 3 Enoch, as well as other texts of Hekhalot tradition, have a well-developed theology connected with this title.

\section{Youth}

It has been already shown that in the descriptions related to Metatron's sacerdotal and liturgical duties he often appears under the title "Youth." Such persistence of the Hekhalot writers who repeatedly connect this designation with Metatron's priestly and liturgical service may be explained by one of the possible meanings of the Hebrew term $r$ ( $n$, which also can be translated as "servant." It should be stressed that the sobriquet "Youth" is never applied to designate the seventh patriarch in 1 Enoch, Jubilees, Genesis Apocryphon, and the Book of Giants. Yet, it is significant that in some manuscripts of Slavonic Enoch for the first time in the Enochic tradition the seventh antediluvian patriarch becomes associated with this prominent Metatron's title. ${ }^{72}$ Despite the fact that this designation occurs only in several Slavonic manuscripts, the author of the recent English translation, Francis Andersen, considered this reading as the original. ${ }^{73} \mathrm{He}$ was also the first scholar to propose that Enoch's designation as "Youth" in 2 Enoch recalls the identical title of Metatron attested in 3 Enoch and other

Journal for the Study of the Pseudepigrapha, Vol. 14, No. 1 (2004): pg. 3-29. DOI. This article is (C) SAGE Publisher and permission has been granted for this version to appear in e-Publications@Marquette. SAGE Publisher does not grant permission for this article to be further copied/distributed or hosted elsewhere without the express permission from SAGE Publisher. 
NOT THE PUBLISHED VERSION; this is the author's final, peer-reviewed manuscript. The published version may be accessed by following the link in the citation at the bottom of the page.

Hekhalot writings. ${ }^{74}$ In his commentary to the English translation of 2 Enoch in OTP, Andersen wrote:

The remarkable reading yunoše [youth], clearly legible in A, supports the evidence of $\mathrm{V}$, which has this variant four times (not here), and of other MSS, that there was a tradition in which Enoch was addressed in this way. The similarity to the vocative enoše [Enoch] might explain the variant as purely scribal slip. But it is surprising that it is only in address, never in description, that the term is used. The variant jenokhu is rare. There is no phonetic reason why the first vowel should change to ju; junokhu is never found. But it cannot be a coincidence that this title is identical with that of Enoch (=Metatron) in 3 Enoch. ${ }^{75}$

The employment of the designation "Youth" in the Slavonic apocalypse cannot be separated from its future usage in the later Merkabah materials, since the context of the usage of the sobriquet is very similar in both traditions. Thus, according to the Merkabah tradition, God likes to address Enoch-Metatron as "Youth." In 3 Enoch 3, when R. Ishmael asks Metatron, "What is your name?" Metatron answers, "I have seventy names, corresponding to the seventy nations of the world ... however, my King calls me 'Youth."'76 The designation of the translated patriarch as "Youth" seems to signify here a special relationship between the deity and Metatron. One can see the beginning of this tradition already in 2 Enoch where in ch. 24 of the shorter recension the following tradition can be found:

And the Lord called me (Enoch) and he placed me to himself closer than Gabriel. And I did obeisance to the Lord. And the Lord spoke to me "Whatever you see, Youth, things standing still and moving about were brought to perfection by me and not even to angels have I explained my secrets... as I am making them known to you today..."77

It is significant that the title "Youth" here is tied to the motif of Enoch's superiority over angels and his leading role in the celestial community which will play later a prominent role in the Merkabah liturgical accounts. It is possible that the title "Youth" also signifies here Enoch's role as a very special servant of the deity who has immediate access to God's Presence which is even closer than that of the archangels. In this context it is not surprising that in the longer recension of $2 \mathrm{En}$. 24.1-2 the patriarch is depicted as the one who has the seat left ${ }^{78}$ of the Lord, "closer than Gabriel," that is, next to God.

Journal for the Study of the Pseudepigrapha, Vol. 14, No. 1 (2004): pg. 3-29. DOI. This article is (C) SAGE Publisher and permission has been granted for this version to appear in e-Publications@Marquette. SAGE Publisher does not grant permission for this article to be further copied/distributed or hosted elsewhere without the express permission from SAGE Publisher. 
NOT THE PUBLISHED VERSION; this is the author's final, peer-reviewed manuscript. The published version may be accessed by following the link in the citation at the bottom of the page.

Finally, we must note that several important readings of "Youth" in the materials associated with Slavonic Enoch can be found in the Vienna Codex. ${ }^{79}$ In this manuscript Enoch is addressed by the Lord as "Youth" 80 in the context of angelic veneration. The passage from 2 Enoch 22 of the Vienna Codex reads:

\begin{abstract}
And the Lord with his own mouth called me [Enoch] and said: Be brave, Youth! ${ }^{81}$ Do not be frightened! Stand up in front of my face forever. And Michael, the Lord's archistratig, brought me in the front of the Lord's face. And the Lord tempted his servants and said to them: "Let Enoch come up and stand in the front of my face forever." And the glorious ones bowed down and said: "Let him come up!"82
\end{abstract}

This veneration of the Youth by the heavenly hosts in the context of God's speech recalls the liturgical accounts found in Synopse 390 and Sefer Haqqomah where the angelic hosts prostrate themselves before the Youth in the Presence of the deity allowing the exalted angel to insert the fire of deafness into their ears. It is not coincidental that scholars previously pointed to the liturgical coloring of this scene from 2 Enoch 22 where the patriarch changes his earthly garments for the luminous attire which now closely resembles the priestly vesture. ${ }^{83}$

\title{
Conclusion
}

The liturgical tradition found in 2 Enoch can be viewed as a bridge that connects the early traditions about the sacerdotal duties of the patriarch found in 1 Enoch and Jubilees with the later Hekhalot and Shicur Qomah lore where references to the translated hero's priestly role are juxtaposed with his liturgical performances. Scholars have previously noted that Enoch's figure portrayed in the various sections of 2 Enoch appears to be more complex than in the early Enochic tractates of 1 Enoch. ${ }^{84}$ For the first time, the Enochic tradition seeks to depict Enoch, not simply as a human taken to heaven and transformed into an angel, but as a celestial being exalted above the angelic world. In this attempt, one may find the origins of another image of Enoch, very different from the early Enochic literature, which was developed much later in Merkabah mysticism-the concept of the supreme angel Metatron, the "Prince of the Presence." 85 The attestation of the seventh antediluvian patriarch as the celestial liturgical director in 2 Enoch gives additional weight to this hypothesis about the

Journal for the Study of the Pseudepigrapha, Vol. 14, No. 1 (2004): pg. 3-29. DOI. This article is (C) SAGE Publisher and permission has been granted for this version to appear in e-Publications@Marquette. SAGE Publisher does not grant permission for this article to be further copied/distributed or hosted elsewhere without the express permission from SAGE Publisher. 
transitionary nature of the Slavonic account which guides the old pseudepigraphical traditions into the new mystical dimension. In this respect the tradition found in 2 Enoch 18 might represent an important step towards defining and shaping Enoch-Metatron's liturgical office in its transition to his new role as the celestial choirmaster. ${ }^{86}$ It is also significant that the beginning of Enoch's liturgical functions in 2 Enoch is conflated there with the development of his new titles-offices as the Youth and the Servant of the Divine Presence which will later play a prominent role in the Merkabah passages pertaining to Metatron's liturgical actions.

Notes

1 P. S. Alexander, "From Son of Adam to a Second God:

Transformation of the Biblical Enoch," in M. E. Stone and T. A. Bergen (eds.), Biblical Figures Outside the Bible (Harrisburg: Trinity Press International, 1998), 87-122 (102-104); H. Odeberg, 3 Enoch or the Hebrew Book of Enoch (New York: Ktav, 1973), 52-63.

2 Alexander, "From Son of Adam to a Second God," 107.

3 On Metatron see, among others, D. Abrams, "The Boundaries of Divine Ontology: The Inclusion and Exclusion of Metatron in the Godhead," HTR 87 (1994) 291-321; P. S. Alexander, "The Historical Setting of the Hebrew Book of Enoch," JJS 28-29 (1977-78) 156180; idem, "3 (Hebrew Apocalypse of) Enoch," OTP, 1.223-315; $\mathrm{H}$. Bietenhard, Die himmlische Welt im Urchristentum und Spätjudentum (WUNT, 2; Tübingen: Mohr/Siebeck, 1951), 143-160; M. Black, "The Origin of the Name Metatron," VT 1 (1951) 217-219; M. S. Cohen, The Shicur Qomah: Liturgy and Theorgy in Pre-Kabbalistic Jewish Mysticism (Lanham, MD: University Press of America, 1983), 124-32; J. Dan, "The Seventy Names of Metatron," in idem, Jewish Mysticism: Late Antiquity (2 vols.; Northvale: Jason Aronson, 1998), 1.229-34; idem, The Ancient Jewish Mysticism (Tel-Aviv: MOD Books, 1993), 108-24; J. R. Davila, "Of Methodology, Monotheism and Metatron," in C. C. Newman, J. R. Davila and G. S. Lewis (eds.), The Jewish Roots of Christological Monotheism: Papers from the St. Andrews Conference on the Historical Origins of the Worship of Jesus (SJSJ, 63; Leiden: Brill, 1999), 3-18; idem, "Melchizedek, the 'Youth,' and Jesus," in J. R. Davila (ed.), The Dead Sea Scrolls as Background to Postbiblical Judaism and Early Christianity: Papers from an International Conference at St. Andrews in 2001 (STDJ, 46; Leiden: Brill, 2003), permission has been granted for this version to appear in e-Publications@Marquette. SAGE Publisher does not grant permission for this article to be further copied/distributed or hosted elsewhere without the express permission from SAGE Publisher. 
248-74; W. Fauth, "Tatrosjah-totrosjah und Metatron in der jüdischen Merkabah-Mystik," JSJ 22 (1991) 40-87; C. Fletcher-Louis, Luke-Acts: Angels, Christology and Soteriology (WUNT, 2/94; Tübingen: Mohr/Siebeck, 1997), 156; D. Halperin, The Faces of the Chariot (Tübingen: Mohr/Siebeck, 1988), 420-27; M. Hengel, Studies in Early Christology (Edinburgh: T\&T Clark, 1995), 191-94; I. Gruenwald, Apocalyptic and Merkavah Mysticism (AGAJU, 17; Leiden: Brill, 1980), 195-206; M. Himmelfarb, "A Report on Enoch in Rabbinic Literature," SBLSP (1978), 259-69; C. Kaplan, "The Angel of Peace, UrielMetatron," Anglican Theological Review 13 (1931), 306-13; M. Idel, "Enoch is Metatron," Immanuel 24/25 (1990) 220-240; idem, The Mystical Experience of Abraham Abulafia (trans. J. Chipman; Albany, NY: State University of New York Press, 1988), 117-19; idem, "Metatron-Comments on the Development of Jewish Myth," in $\mathrm{H}$. Pediah (ed.), Myth in Jewish Thought (Ber Sheva: Ber Sheva University Press, forthcoming); S. Lieberman, Ny(yq\# (Jerusalem, 1939), 11-16; idem, "Metatron, the Meaning of his Name and his Functions," Appendix to Gruenwald, Apocalyptic and Merkavah Mysticism, 235-41; M. Mach, Entwicklungsstadien des jüdischen Engelglaubens in vorrabbinischer Zeit (TSAJ, 34; Tübingen: Mohr/Siebeck, 1992), 394-96; R. Margaliot, Nwyl ( yk) lm (Jerusalem: Mossad Harav Kook, 1964), 73-108; J. Milik, The Books of Enoch (Oxford: Clarendon, 1976), 125-35; G. F. Moore, "Intermediaries in Jewish Theology: Memra, Shekinah, Metatron," HTR 15 (1922) 41-85; C. Mopsik, Le Livre hébreu d'Hénoch ou Livre des palais (Paris: Verdier, 1989), 44-48; C. R. A. Morray-Jones, "Transformational Mysticism in the Apocalyptic-Merkabah Tradition," JJS 43 (1992) 131(7-11); A. Murtonen, "The Figure of Metatron," VT 3 (1953) 409-11; H. Odeberg, "Föreställningarna om Metatron i äldre judisk mystic," Kyrkohistorisk Arsskrift 27 (1927), 1-20; idem, 3 Enoch, or the Book of Enoch, 79-146; idem, "Enoch," in TDNT, 2.556-60; A. Orlov, "Titles of Enoch-Metatron in 2 Enoch," JSP 18 (1998) 71-86; idem, "The Origin of the Name 'Metatron' and the Text of 2 (Slavonic Apocalypse), of Enoch," JSP 21 (2000) 19-26; P. Schäfer, Hidden and Manifest God: Some Major Themes in Early Jewish Mysticism (Albany, NY: State University of New York Press, 1992), 29-32; G. Scholem, Major Trends in Jewish Mysticism (Jerusalem: Schocken, 1941), 43-55; idem, Jewish Gnosticism, Merkabah Mysticism, and Talmudic Tradition (New York: Jewish Theological Seminary of America, 1960), 43-55; idem, permission has been granted for this version to appear in e-Publications@Marquette. SAGE Publisher does not grant permission for this article to be further copied/distributed or hosted elsewhere without the express permission from SAGE Publisher. 
"Metatron," in EncJud, 11.1443-46; idem, Kabbalah (New York: Dorset, 1987), 377-81; idem, Origins of the Kabbalah (Princeton, NJ; Princeton University Press, 1990), 214-15; A. F. Segal, Two Powers in Heaven: Early Rabbinic Reports about Christianity and Gnosticism (SJLA, 25; Leiden: Brill, 1977), 60-73; G. G. Stroumsa, "Form(s), of God: Some Notes on Metatron and Christ," HTR 76 (1983) 269-88; L. T. Stuckenbruck, Angel Veneration and Christology (WUNT, 2.70; Tübingen: Mohr/Siebeck, 1995), 71-73; I. Tishby, The Wisdom of the Zohar (3 vols.; London: The Littman Library of Jewish Civilization, 1989), 2.626-32; G. Vajda, "Pour le Dossier de Metatron," in S. Stein and R. Loewe (eds.), Studies in Jewish Religious and Intellectual History Presented to A. Altmann (Alabama: University of Alabama Press, 1979), 345-54; E. E. Urbach, The Sages, Their Concepts and Beliefs (trans. I. Abrahams; 2 vols.; Jerusalem: Magnes Press, 1975), 1.138-39; 2.743-44; E. Wolfson, Through a Speculum that Shines: Vision and Imagination in Medieval Jewish Mysticism (Princeton, NJ: Princeton University Press, 1994), 113, 334; idem, "Metatron and Shicur Qomah in the Writings of Haside Ashkenaz," in Karl E. Groezinger and J. Dan (eds.), Mysticism, Magic and Kabbalah in Ashkenazi Judaism (Berlin: W. de Gruyter, 1995), 60-92.

4 Alexander, "3 (Hebrew Apocalypse of), Enoch," 303.

5 The literary integrity of Sefer Hekhalot is a complicated issue. The form of the work in the major manuscripts demonstrates "clear signs of editing." Scholars observe that "3 Enoch has arisen through the combination of many separate traditions: it tends to break down into smaller 'self-contained' units which probably existed prior to their incorporation into the present work... It is not the total product of a single author at particular point in time, but the deposits of a 'school tradition' which incorporates elements from widely different periods" (Alexander, "3 Enoch," 223). Alexander also observes that "an inspection of the textual tradition shows that chapters 3-15/16, which describe the elevation of Enoch, circulated as an independent tract...and it is intrinsically probable that these chapters formed the core round which the longer recensions grew" (Alexander, "The Historical Settings of the Hebrew Book of Enoch," 156-7). The detailed discussion of the literary character of 3 Enoch and its possible transmission history transcends the boundaries of current investigation. 
NOT THE PUBLISHED VERSION; this is the author's final, peer-reviewed manuscript. The published version may be accessed by following the link in the citation at the bottom of the page.

6 MS New York JTS 8128.

7 Peter Schäfer, with M. Schlüter and H. G. von Mutius., Synopse zur Hekhalot-Literatur (TSAJ, 2; Tübingen: Mohr/Siebeck, 1981), 164. ${ }^{8}$ Another Hekhalot passage attested in Synopse $\S 385$ also elaborates the liturgical role of the exalted angel: "...when the youth enters below the Throne of Glory, God embraces him with a shining face. All the angels gather and address God as 'the great, mighty, awesome God,' and they praise God three times a day by means of the youth ( $r$ ( $\mathrm{nh}$ dy 1 (Mwy Mym (p h\#l\# h`b`qh Myxb\#mw)..." Schäfer, Synopse, 16263.

9 Schäfer, Hidden and Manifest God, 25.

10 Synopse 104 reads: "The voice of the first one: one who hears [this] voice, will immediately go mad and tumble down. The voice of the second one: everyone who hears it, immediately goes astray and does not return. The voice of the third one: one who hears [this] voice is struck by cramps and he dies immediately...." Schäfer, Hidden and Manifest God, 25.

${ }^{11}$ On this motif of the dangerous encounters with the divine in the Hekhalot literature, see J.R. Davila, Descenders to the Chariot: The People Behind the Hekhalot Literature (SJSJ, 70; Leiden: Brill, 2001), 136-39.

12 It appears that the angelic hosts must be protected, not for the whole course of the celestial liturgy, but only during the invocation of the divine name. Cf. M. S. Cohen, The Shi cur Qomah: Texts and Recensions (TSAJ, 9; Tübingen: Mohr/Siebeck, 1985), 162-63.

$13 \mathrm{M}$. Himmelfarb, "The Temple and the Garden of Eden in Ezekiel, the Book of the Watchers, and the Wisdom of Ben Sira," in Jamie Scott and Paul Simpson-Housley (eds.), Sacred Places and Profane Spaces: Essays in the Geographics of Judaism, Christianity, and Islam (New York: Greenwood Press, 1991), 63-78; idem, "Apocalyptic Ascent and the Heavenly Temple," SBLSP 26 (1987) 210-17. Himmelfarb's research draws on the previous publications of J. Maier and G. W. E. Nickelsburg; cf. J. Maier, "Das Gefährdungsmotiv bei der Himmelsreise in der jüdischen Apocalyptik und ,Gnosis,'" Kairos 5.1 (1963) 18-40, (23); idem, Vom Kultus zur Gnosis: Studien zur Vor-und Frühgeschichte der "Judischen Gnosis." Bundeslade, Gottesthron und Märkabah (Kairos, 1; Salzburg: Müller, 1964), 127-8; G. W. E. Nickelsburg, "Enoch, Levi, and Peter: Recipients of Revelation in Upper Galilee" JBL 100 (1981) 575-600 (576-82). Cf. also H. Kvanvig, Roots

Journal for the Study of the Pseudepigrapha, Vol. 14, No. 1 (2004): pg. 3-29. DOI. This article is (C) SAGE Publisher and permission has been granted for this version to appear in e-Publications@Marquette. SAGE Publisher does not grant permission for this article to be further copied/distributed or hosted elsewhere without the express permission from SAGE Publisher. 
of Apocalyptic: The Mesopotamian Background of the Enoch Figure and of the Son of Man (WMANT, 61; Neukirchen-Vluyn: Neukirchener Verlag, 1988), 101-102; Halperin, The Faces of the Chariot, 81. ${ }^{14}$ M. Knibb, The Ethiopic Book of Enoch (2 vols.; Oxford: Clarendon Press, 1978), 1.50-52; 2.98-99.

${ }^{15}$ Himmelfarb, "Apocalyptic Ascent and the Heavenly Temple," 210. ${ }^{16}$ One comment must be made about the early traditions and sources that may lie behind the descriptions of the upper sanctuary in $1 \mathrm{En}$. 14. Scholars observe that the idea of heaven as a temple was not invented by the author of the Book of the Watchers since the concept of the heavenly temple as a heavenly counterpart of the earthly sanctuary was widespread in the ancient Near East and appears in a number of biblical sources. Cf. Himmelfarb, "The Temple and the Garden of Eden," 68. Students of Jewish priestly traditions previously noted that the existence of such a conception of the heavenly sanctuary appears to become increasingly important in the times of religious crises when the earthly sanctuaries were either destroyed or "defiled" by "improper" rituals or priestly successions. For an extensive discussion of this subject, see B. Ego et al. (eds.), Gemeinde ohne Tempel/Community Without Temple: Zur Substituierung und Transformation des Jerusalemer Tempels und seines Kults im Alten Testament, antiken Judentum und frühen Christentum (WUNT, 118; Tübingen: Mohr/Siebeck, 1999); R. Elior, "From Earthly Temple to Heavenly Shrines: Prayer and Sacred Song in the Hekhalot Literature and Its Relation to Temple Traditions," JSQ 4 (1997) 217-67; idem, "The Priestly Nature of the Mystical Heritage in Heykalot Literature," in R.B. Fenton and R. Goetschel (eds.), Expérience et écriture mystiques dans les religions du livre: Actes d'un colloque international tenu par le Centre d'études juives Université de Paris IV-Sorbonne 1994 (EJM, 22; Leiden: Brill, 2000), 41-54.

17 Himmelfarb, "Apocalyptic Ascent and the Heavenly Temple," 211. ${ }^{18}$ Himmelfarb, "Apocalyptic Ascent and the Heavenly Temple," 211. David Halperin also supports this position. In his view, "the angels, barred from the inner house, are the priests of Enoch's heavenly Temple. The high priest must be Enoch himself, who appears in the celestial Holy of Holies to procure forgiveness for holy beings"(Haplerin, The Faces of the Chariot, 82).

${ }^{19}$ Halperin's studies also stress the apocalyptic priestly function of Enoch in the Book of the Watchers. He observes that "Daniel and

Journal for the Study of the Pseudepigrapha, Vol. 14, No. 1 (2004): pg. 3-29. DOI. This article is (C) SAGE Publisher and permission has been granted for this version to appear in e-Publications@Marquette. SAGE Publisher does not grant permission for this article to be further copied/distributed or hosted elsewhere without the express permission from SAGE Publisher. 
Enoch share an image, perhaps drawn from the hymnic tradition of merkabah exegesis (think of the Angelic liturgy), of God surrounded by multitudes of angels. But, in the Holy of Holies, God sits alone.... The angels, barred from the inner house, are the priests of Enoch's heavenly Temple. The high priest must be Enoch himself, who appears in the celestial Holy of Holies to procure forgiveness for holy beings" (Halperin, Faces of the Chariot, 81-82).

20 Himmelfarb, "Apocalyptic Ascent and the Heavenly Temple," 213.

${ }^{21}$ George Nickelsburg's earlier study on the temple symbolism in 1 En. 14 provides some important additional details relevant to our ongoing discussion. Nickelsburg argues that Enoch's "active" involvement in the vision of the Lord's Throne, when he passes through the chambers of the celestial sanctuary, might indicate that the author(s), of the Book of the Watchers perceived him as a servant associated with the activities in these chambers. Nickelsburg points to the fact that Enoch's vision of the Throne in the Book of the Watchers is "qualitatively different from that described in the biblical throne visions" by way of the new active role of its visionary. This new, active participation of Enoch in the vision puts $1 \mathrm{En}$. 14 closer to later Merkabah accounts which are different from biblical visions. Nickelsburg stresses that in the biblical throne visions, the seer is passive or, at best, his participation is reactional. In contrast, in the Merkabah accounts, Enoch appears to be actively involved in his vision. In Nickelsburg's view, the verbal forms of the narrative ("I drew near the wall," "I went into that house"), serve as further indications of the active "participation" of the seer in the visionary "reality" of the heavenly Throne/Temple. On the other hand, biblical visions are not completely forgotten by Enochic authors and provide an important exegetical framework for 1 En. 14. Comparing the Enochic vision with the Ezekelian account of the temple, Nickelsburg suggests that the Enochic narrative also represents a vision of the temple, but, in this case, the heavenly one. He argues that "the similarities to Ezek. 4048 , together with other evidence, indicate that Enoch is describing his ascent to the heavenly temple and his progress through its temenos to the door of the holy of holies, where the chariot throne of God is set" (Nickelsburg, "Enoch, Levi, and Peter," 579-81).

22 Himmelfarb, "Apocalyptic Ascent and the Heavenly Temple," 212.

${ }^{23}$ Knibb. The Ethiopic Book of Enoch, 1.294; 2.198. permission has been granted for this version to appear in e-Publications@Marquette. SAGE Publisher does not grant permission for this article to be further copied/distributed or hosted elsewhere without the express permission from SAGE Publisher. 
${ }^{24}$ Cf. 1 En. 89:50: "And that house became large and broad, and for those sheep a high tower was built on that house for the Lord of the sheep; and that house was low, but the tower was raised up and high; and the Lord of the sheep stood on that tower, and they spread a full table before him" (Knibb, The Ethiopic Book of Enoch, 2.208); 1 En. 89.73: "And they began again to build, as before, and they raised up that tower, and it was called the high tower; and they began again to place a table before the tower, but all the bread on it (was), unclean and was not pure" (Knibb, The Ethiopic Book of Enoch, 2.211).

25 J. VanderKam, Enoch: A Man for All Generations (Columbia, SC: University of South Carolina Press, 1995), 117.

${ }^{26}$ VanderKam, Enoch: A Man for All Generations, 117.

27 For Enoch's place in the heavenly Paradise, see Testament of Benjamin 10:6; Apocalypse of Paul 20; Clementine Recognitions 1:52; Acts of Pilate 25; and the Ascension of Isaiah 9:6. Cf. C. Rowland, "Enoch," in K. van der Toorn et al. (eds.), Dictionary of Deities and Demons in the Bible (Leiden: Brill, 1999), 302.

28 J. VanderKam, The Book of Jubilees (2 vols.; CSCO, 510-11; Scriptores Aethiopici, 87-88; Leuven: Peeters, 1989), 2.28.

29 VanderKam argues that there are other indications that in the book of Jubilees Eden was understood as a sanctuary. As an example, he points to Jub. 3.9-14, which "derives the law from Lev 11 regarding when a women who has given birth may enter the sanctuary from the two times when Adam and Eve, respectively, went into the garden" (VanderKam, Enoch: A Man for All Generation, 117).

30 One must note the peculiar details surrounding the depiction of Enoch's priestly duties in early Enochic lore. While the Book of the Watchers does not refer to any liturgical or sacrificial rituals of the patriarch, Jubilees depicts the patriarch offering incense to God. The absence of references to any animal sacrificial or liturgical practice in Enoch's sacerdotal duties might indicate that his office may have been understood by early Enochic traditions to be of the "divinatory angle," that is, as the office of oracle-priest, practiced also by the Mesopotamian diviners who, similarly to Enoch's preoccupation with incense, widely used the ritual of libanomancy, or smoke divination, a "practice of throwing cedar shavings onto a censer in order to observe the patterns and direction of the smoke" (M. S. Moore, The Balaam Traditions: Their Character and Development [SBLDS, 113; Atlanta, GA: Scholars Press, 1990], 43).

Journal for the Study of the Pseudepigrapha, Vol. 14, No. 1 (2004): pg. 3-29. DOI. This article is (C) SAGE Publisher and permission has been granted for this version to appear in e-Publications@Marquette. SAGE Publisher does not grant permission for this article to be further copied/distributed or hosted elsewhere without the express permission from SAGE Publisher. 
NOT THE PUBLISHED VERSION; this is the author's final, peer-reviewed manuscript. The published version may be accessed by following the link in the citation at the bottom of the page.

31 VanderKam, The Book of Jubilees, 2.28.

32 VanderKam, Enoch: A Man for All Generations, 117.

${ }^{33}$ VanderKam, Enoch: A Man for All Generations, 117. Scholars point to the possible polemical nature of the patriarch's priestly role.

Gabriele Boccaccini observes that "Enochians completely ignore the Mosaic torah and the Jerusalem Temple, that is the two tenets of the order of the universe." In his opinion, "the attribution to Enoch of priestly characteristics suggests the existence of a pure prediluvian, and pre-fall, priesthood and disrupts the foundation of the Zadokite priesthood, which claimed its origin in Aaron at the time of exodus, in an age that, for the Enochians, was already corrupted after the angelic sin and the flood" (G. Boccaccini, Beyond the Essene Hypothesis: The Parting of the Ways between Qumran and Enochic Judaism [Grand Rapids: Eerdmans, 1998], 74).

34 Knibb, The Ethiopic Book of Enoch, 2.127.

35 It should be noted that the expression "the tabernacle of the Youth" occurs also in the Shicur Qomah materials. For a detailed analysis of the Metatron imagery in this tradition, see Cohen, Liturgy and Theurgy in Pre-Kabbalistic Jewish Mysticism, 124-32.

36 Midrash Rabbah (10 vols.; London: Soncino Press, 1961), 5.482-83.

37 Cf. Sefer Haqqomah 155-164; Sid. R. 37-46.

383 En. 8.1: "R. Ishmael said: Metatron, Prince of the Divine Presence, said to me: Before the Holy One, blessed be he, set me to serve the throne of glory...." (Alexander, "3 Enoch," 262). Metatron's prominent role might be also reflected in the fragment found on one magic bowl where he is called hysrwkd ) br ) rsy) ("the great prince of the throne"); see C. Gordon, "Aramaic Magical Bowls in the Istanbul and Baghdad Museums," Archiv Orientálni 6 (1934) 319-34 (328).

39 Alexander, "3 Enoch," 303.

40 On the title "Youth" in the Hekhalot literature, see Davila, "Melchizedek, the 'Youth,' and Jesus," 254-66, and Halperin, Faces of the Chariot, 491-94.

${ }^{41}$ Cf., for example, Synopse 385: "when the youth enters beneath the throne of glory (dwbkh ) sk txtl r(nh snkn)" (Schäfer, Synopse, p.162). Another text preserved in the Cairo Genizah also depicts the "youth" as emerging from his sacerdotal place in the immediate Presence of the deity: "Now, see the youth, who is going forth to meet you from behind the throne of glory. Do not bow down to him, because his crown is like the crown of his King..." (P. Schäfer, Geniza- 
NOT THE PUBLISHED VERSION; this is the author's final, peer-reviewed manuscript. The published version may be accessed by following the link in the citation at the bottom of the page.

Fragmente zur Hekhalot-Literatur [TSA], 6; Tübingen: Mohr/Siebeck, 1984)], 2b.13-14).

42 On the imagery of the Celestial Curtain, see also b. Yom 77a; b. Ber 18b; 3 En. 45.1.

43 On the celestial curtain Pargod as the heavenly counterpart of the paroket, the veil of the Jerusalem Temple, see D. Halperin, The Merkabah in Rabbinic Literature (AOS, 62; New Haven: American Oriental Society, 1980), 169 n. 99; C. R. A. Morray-Jones, A Transparent Illusion: The Dangerous Vision of Water in Hekhalot Mysticism (Leiden: Brill, 2002), 164-168.

44 W. S. McCullough, Jewish and Mandean Incantation Texts in the Royal Ontario Museum (Toronto: University of Toronto Press, 1967), D 5-6.

45 Alexander, "The Historical Settings of the Hebrew Book of Enoch," 166.

46 The passage found in Synopse 385 relates: "when the youth enters beneath the throne of glory, God embraces him with a shining face."

47 Elior, "From Earthly Temple to Heavenly Shrines," 228.

${ }^{48}$ L. H. Schiffman and M. D. Swartz, Hebrew and Aramaic Incantation

Texts from the Cairo Genizah (Semitic Texts and Studies, 1; Sheffield: Sheffield Academic Press, 1992), 145-47, 151. On Metatron as the high priest, see Schiffman and Swartz, Hebrew and Aramaic Incantation Texts, 25-28, 145-47, 156-57; Elior, "From Earthly Temple to Heavenly Shrines," 299 n. 30. Al-Qirquisani alludes to the evidence from the Talmud about the priestly function of Metatron. See $\mathrm{L}$.

Ginzberg, The Legends of the Jews (trans. H. Szold; 7 vols.; Baltimore: The John Hopkins University Press, 1998), 6.74.

${ }^{49}$ Cf. also $b$. Ket 105b; b. Hull. 49a.

50 Elior, "From Earthly Temple to Heavenly Shrines," 225.

${ }^{51}$ Cf., e.g., 3 En. 2.3: "Metatron replied, 'He [R. Ishmael] is of the tribe of Levi, which presents the offering to his name. He is of the family of Aaron, whom the Holy One, blessed be he, chose to minister in his presence and on whose head he himself placed the priestly crown on Sinai'" (Alexander, "3 Enoch," 257).

$52 \mathrm{~N}$. Deutsch observes that in 3 Enoch "likewise, as the heavenly high priest, Metatron serves as the mythological prototype of Merkabah mystics such as Rabbi Ishmael. Metatron's role as a high priest highlights the functional parallel between the angelic vice regent and the human mystic (both are priests), whereas his transformation from

Journal for the Study of the Pseudepigrapha, Vol. 14, No. 1 (2004): pg. 3-29. DOI. This article is (C) SAGE Publisher and permission has been granted for this version to appear in e-Publications@Marquette. SAGE Publisher does not grant permission for this article to be further copied/distributed or hosted elsewhere without the express permission from SAGE Publisher. 
a human being into an angel reflects an ontological process which may be repeated by mystics via their own enthronement and angelification" (N. Deutsch, Guardians of the Gate: Angelic Vice Regency in Late Antiquity [BSJS, 22; Leiden: Brill, 1999], 34).

53 Alexander, "From Son of Adam to a Second God," 106-107.

${ }^{54}$ Cohen, The Shicur Qomah, 162-64.

55 Cohen, The Shicur Qomah: Texts and Recensions, 162-64. On the relation of this passage to the Youth tradition see Davila, "Melchizedek, the 'Youth,' and Jesus," 248-74.

${ }^{56}$ Cohen, The Shicur Qomah: Liturgy and Theurgy in Pre-Kabbalistic Jewish Mysticism, 134.

57 This tradition is not forgotten in the later Jewish mystical developments. Thus, Daniel Abrams notes that in Sefer ha-Hashek "Metatron commands the angels to praise the King of the Glory, and he is among them" (Abrams, "The Boundaries of Divine Ontology," 304.

58 Alexander, "3 Enoch," 256. Peter Schäfer suggests that Ishmael's example stresses the connection between heavenly and earthly liturgies; cf. Schäfer, The Hidden and Manifest God, 132.

$59 \mathrm{M}$. Himmelfarb observes that "the combination of clothing and anointing suggests that the process by which Enoch becomes an angel is a heavenly version of priestly investiture" (M. Himmelfarb, Ascent to Heaven in Jewish and Christian Apocalypses [New York, Oxford: Oxford University Press, 1993], 40).

60 Slav. $\sigma \lambda v / \imath \varepsilon$. M. I Sokolov, "Materialy i zametki po starinnoj slavjanskoj literature. Vypusk tretij, VII. Slavjanskaja Kniga Enoha Pravednogo. Teksty, latinskij perevod i izsledovanie. Posmertnyj trud avtora prigotovil k izdaniju M. Speranskij," Chtenija v Obshchestve Istorii i Drevnostej Rossijskih 4 (1910), 16.

${ }^{61}$ Slav. $\sigma \lambda v(\beta 1 \varpi \alpha) \varepsilon$. Sokolov, "Materialy i zametki po starinnoj slavjanskoj literature," 16.

${ }^{62} \mathrm{~F}$. Andersen, "2 (Slavonic Apocalypse of) Enoch," in OTP, 1.91-221 (132).

63 The shorter recension of 2 En. 18.8-9 reads: "And why don't you perform the liturgy before the face of the Lord? Start up the former liturgy. Perform the liturgy in the name of fire (vo imja ogne), lest you annoy the Lord your God (so that), he throws you down from this place.' And they heeded the earnestness of my recommendation, and they stood in four regiments in heaven. And behold, while I was 
standing, they sounded with 4 trumpets in unison, and the Grigori began to perform the liturgy as with one voice. And their voices rose up in the Lord's presence" (Andersen, "2 Enoch," 133).

64 Andersen, "2 Enoch," 133.

65 Andersen, "2 Enoch," 133.

${ }^{66}$ Although the imagery of angels of the Presence was widespread in the pseudepigraphical writings and specifically in the early Enochic pseudepigrapha, it was never explicitly identified with the seventh antediluvian patriarch. 1 En. 40:9, however, mentions the four "Faces" or "Presences" of Ezek. 1:6 identifying them with the four principal angels: Michael, Phanuel, Raphael, and Gabriel.

67 Odeberg, 3 Enoch, 55.

${ }^{68}$ Cf. 2 En. 21:3: "And the Lord send one of his glorious ones, the archangel Gabriel. And he said to me 'Be brave, Enoch! Don't be frightened! Stand up, and come with me and stand in front of the face of the Lord forever."' 2 En. 22:6: "And the Lord said to his servants, sounding them out: 'Let Enoch join in and stand in front of my face forever!"' 2 En. 36:3: "Because a place has been prepared for you, and you will be in front of my face from now and forever" (Andersen, "2 Enoch," 136, 138, 161).

69 Scholem, Major Trends in Jewish Mysticism, p. 67.

70 On the debates about the various stages in the development of the Merkabah tradition, see Alexander, "The Historical Setting of the Hebrew Book of Enoch," 173-80; David J. Halperin, "A New Edition of the Hekhalot Literature," JAOS 104.3 (1984) 543-52; idem, The Faces of the Chariot: Early Jewish Responses to Ezekiel's Vision, 359-63; Himmelfarb, Ascent to Heaven in Jewish and Christian Apocalypses, 106-14; idem, "The Experience of the Visionary and the Genre in the Ascension of Isaiah 6-11 and the Apocalypse of Paul," Semeia 36 (1986) 97-111; idem, "The Practice of Ascent in the Ancient Mediterranean World," in J. J. Collins and M. Fishbane (eds.), Death, Ecstasy, and Other Worldly Journeys (Albany, NY: State University of New York Press, 1995), 123-37 (126-28); Gruenwald, Apocalyptic and Merkavah Mysticism, 67, 98-123; Maier, Vom Kultus zur Gnosis, 12846; Peter Schäfer, "Prolegomena zu einer kritischen Edition und Analyse der Merkava Rabba," FJB 5 (1977), 65-99; idem, "Die Beschwöerung des sar ha-panim, Kritische Edition und Übersetzung," FJB 6 (1978) 107-45; idem, "Aufbau und redaktionelle Identität der Hekhalot Zutarti," JJS 33 (1982) 569-82; "Tradition and Redaction in 
Hekhalot Literature," JSJ 14 (1983) 172-81; idem, "Engel und Menschen in der Hekhalot-Literatur," in idem, Hekhalot-Studien (TSAJ, 19; Tübingen: Mohr/Siebeck, 1988), 250-76 (258, 264-65); idem, "The Aim and Purpose of Early Jewish Mysticism: Gershom Scholem Reconsidered," 277-95 in the same volume; idem, The Hidden and Manifest God, 150-55; Scholem, Major Trends in Jewish Mysticism, 4344; Michael D. Swartz, Scholastic Magic: Ritual and Revelation in Early Jewish Mysticism (Princeton, NJ: Princeton University Press, 1996), 29, 153-57; 170-72; 210-12; Ephraim E. Urbach, "The Traditions about Merkavah Mysticism in the Tannaitic Period," in E. E. Urbach, R. J. Zwi Werblowsky and Ch. Wirszubski (eds.), Studies in Mysticism and Religion Presented to Gershom G. Scholem on His Seventieth Birthday by Pupils, Colleagues and Friends (Jerusalem: Magnes Press, 1967), 128 (Hebrew).

71 Scholem, Major Trends in Jewish Mysticism, 67.

72 Slav. Jvo $\varepsilon$.

73 Professor Francis Andersen reassured me in a private communication about the originality of this reading, referring to it as "powerful evidence."

74 See, for example, §§384, 385, 390, 396 in Schäfer, Synopse, 16263, 164-65, 166-67.

75 Andersen, "2 Enoch," 118-19.

76 Alexander, "3 Enoch," 257.

78 Sokolov, "Materialy i zametki po starinnoj slavjanskoj literature," 90-91.

78 Andersen, "2 Enoch," 119.

78 The assigning of the left side to the vice-regent might be seen as puzzling. Martin Hengel, however, rightly observes that this situation can be explained as the correction of the Christian scribe(s), who "reserved this place for Christ" (M. Hengel, Studies in Early Christology [Edinburg: T.\&T. Clark, 1995], 193). Hengel points to a similar situation in the Ascension of Isaiah where the angel of the holy spirit is placed at the left hand of God.

${ }^{79}$ I want to express my deep gratitude to Professor Francis Andersen who generously shared with me the microfilms and photographs of MSS V, R, and J.

80 Unfortunately, Friedrich Repp's research on the Vienna Codex failed to discern the proper meaning of "Youth" in this important manuscript. See F. Repp, "Textkritische Untersuchungen zum Henoch-Apokryph

Journal for the Study of the Pseudepigrapha, Vol. 14, No. 1 (2004): pg. 3-29. DOI. This article is (C) SAGE Publisher and permission has been granted for this version to appear in e-Publications@Marquette. SAGE Publisher does not grant permission for this article to be further copied/distributed or hosted elsewhere without the express permission from SAGE Publisher. 
NOT THE PUBLISHED VERSION; this is the author's final, peer-reviewed manuscript. The published version may be accessed by following the link in the citation at the bottom of the page.

des co. slav. 125 der Österreichischen Nationalbibliothek," Wiener slavistische Jahrbuch 10 (1963), 58-68 (65).

${ }^{81}$ Slav. J vo $)_{\varepsilon .}$

82 MS V (VL 125), [Nr. 3], fol. 317.

83 Himmelfarb, Ascent to Heaven in Jewish and Christian Apocalypses, 40.

${ }^{84}$ Alexander, "From Son of Adam to a Second God," 102-104; Odeberg, 3 Enoch, 52-63.

$85 \mathrm{P}$. Alexander observes that "the transformation of Enoch in 2 Enoch 22 provides the closest approximation, outside Merkabah literature, to Enoch's transformation in 3 Enoch 3-13" (Alexander, "3 Enoch," 248). ${ }^{86}$ It is intriguing that a similar or maybe even competing development can be detected in the early lore about Yahoel. Thus, Apoc. Abr. 10:9 depicts Yahoel as the one who is responsible for teaching "those who carry the song through the medium of man's night of the seventh hour" (R. Rubinkiewicz, "Apocalypse of Abraham," in OTP, 1.694). In ch. 12 of the same text Abraham addresses to Yahoel as "Singer of the Eternal One."

Journal for the Study of the Pseudepigrapha, Vol. 14, No. 1 (2004): pg. 3-29. DOI. This article is @ SAGE Publisher and permission has been granted for this version to appear in e-Publications@Marquette. SAGE Publisher does not grant permission for this article to be further copied/distributed or hosted elsewhere without the express permission from SAGE Publisher. 
NOT THE PUBLISHED VERSION; this is the author's final, peer-reviewed manuscript. The published version may be accessed by following the link in the citation at the bottom of the page.

Journal for the Study of the Pseudepigrapha, Vol. 14, No. 1 (2004): pg. 3-29. DOI. This article is (C) SAGE Publisher and permission has been granted for this version to appear in e-Publications@Marquette. SAGE Publisher does not grant permission for this article to be further copied/distributed or hosted elsewhere without the express permission from SAGE Publisher. 
NOT THE PUBLISHED VERSION; this is the author's final, peer-reviewed manuscript. The published version may be accessed by following the link in the citation at the bottom of the page.

Journal for the Study of the Pseudepigrapha, Vol. 14, No. 1 (2004): pg. 3-29. DOI. This article is (C) SAGE Publisher and permission has been granted for this version to appear in e-Publications@Marquette. SAGE Publisher does not grant permission for this article to be further copied/distributed or hosted elsewhere without the express permission from SAGE Publisher. 